\title{
Marlowe, Christopher.
}

\section{The Jew of Malta, ed. Mathew R. Martin.}

Peterborough, ON: Broadview Editions, 2012. Pp. 289. ISBN 978-1-55481-068-0 (paperback) \$18.95.

The Jew of Malta is one of a group of late-Elizabethan texts in which-strangely for a country in which no significant Jewish community had been permitted for fully three centuries-ideas about Jewishness, most of them anti-Semitic, are strongly foregrounded. Mathew Martin's new edition of the play, with its wideranging and thoughtful introduction and four substantial appendices, provides critical guidance and a well-chosen array of primary contextual materials which readers of all kinds will find useful in making sense of a controversial play-text that also remains, in its vicious hilarity, eminently stage-worthy.

Harold Bloom claimed, misleadingly I think, that The Jew of Malta pushes anti-Semitic tropes so far into farce and absurdity that they are effectively defanged. But contextualizing analyses of the kind this edition will encourage should permit a more nuanced understanding of the matter.

In his first appendix, Martin excerpts two scenes from Robert Wilson's Three Ladies of London (1584) in which Mercadorus, a London-based merchant who speaks a generically "foreign" English, seeks in Turkey to cheat the Jew Gerontus out of the large sum he owes him by converting to Islam (which by Turkish law would free him from prior debts). Rather than see even so crooked a Christian commit apostasy, the humane Gerontus forgives the debt and shows no resentment when Mercadorus gloats over having "cozened de Jew."

Marlowe's Barabas (whose only offence, beyond an arrogant narcissism, has been the greed that motivates him to enclose "Infinite riches in a little room") is similarly cheated by dishonest Christians, who after seizing his property in order to pay the tribute owing to the Turks, keep it even once they've decided to refuse the tribute. The play devolves into a sequence of farcical acts of revenge and cover-up, but the notion that Christians are ethically inferior to Jews remains in circulation: Barabas may outdo in malice the Christians who have robbed him, but he is scarcely their equal in hypocrisy. The Jew of Malta, in short, is anti-Semitic, but its anti-Semitism is, at least in part, a means of leveraging a satirical onslaught against Christian mores. 
A comparison with the vehemently anti-Semitic passages excerpted by Martin from Thomas Nashe's The Unfortunate Traveller (1594) may be instructive. In Nashe's text, Dr. Zacharie intends to bleed the captive protagonist to death (thus parodying kosher rules and evoking the blood-libel), while another Jewish villain, Zadoch, plans an orgy of violence involving a cluster of antiSemitic tropes: well-poisoning, slaughtering children (and feeding galley-slaves with their pickled flesh), poisoning the hosts used in holy communion, and spreading plague. In contrast, the crimes Barabas boasts of to his slave Ithimore include only two with a specifically anti-Semitic tone (well-poisoning, and driving people to suicide with usury), while the murders dramatized in the play-poisoning Isabella and her nunnery, strangling one friar and framing another, and poisoning Ithimore, Bellamira, and Pilia-Borza-all follow from Barabas's attempt to conceal his responsibility for the deaths of Lodowick and Mathias. The blood-libel is alluded to in the play, but only in Friar Jacomi's question: "What, hath he crucified a child?" (3.6.49).

Martin rather oddly includes in his first appendix a six-page excerpt from Sir Thomas Browne's Pseudodoxia epidemica refuting the anti-Semitic trope of the foetor judaicus. But this trope occurs in the play only in inverted form, as a foetor christianus-alluded to by Barabas when he tells Lodowick, "Tis a custom held with us / That, when we speak with gentiles like to you, / We turn into the air to purge ourselves" (2.3.45-47); and again when he notes the arrival of the two friars by saying, "I smelt 'em ere they came" (4.1.19-20). It might have been of greater value to include material related to Jonathan Gil Harris's telling perception that Barabas's action in leading the invading Turks into Malta through its sewers amounts to a violation of the social body by its abjected other-especially since this would link up to what Martin himself says about abjection in the excellent and well-informed discussion of early modern anti-Semitism in his introduction.

The materials in Martin's other appendices-on European-Ottoman relations, Machiavellianism, and Marlowe's reputation—are all stimulating, though more could perhaps have been made of the fact that accusers like Robert Greene and Richard Baines appear to have regarded Marlowe's Machiavellianism, "atheism," and scepticism as components of a single toxic brew. But here one is perhaps asking for more of a good thing than the format of the Broadview Editions is able to accommodate. 
The sustained excellence of Martin's introduction is marred by two small errors. It is surely misleading to say that a BA degree entitled Marlowe "to style himself 'Sir Christopher Marlowe"' (11). (Constance Kuriyama, whose 2002 Marlowe biography Martin follows here, is referring to a not-for-export academic title, an English equivalent to the Latin "Ds." or "Dominus" - but in Shakespeare's Twelfth Night, the faux-cleric Sir Topas is not in anyone's estimate the social equal of a knight or baronet like Sir Toby Belch or Sir Andrew Aguecheek.) Secondly, it seems uncalled-for to describe as "conspiracy theories" the analyses that have led to the conclusion that Marlowe's death was a political murder, rather than the result of "a quarrel over lunch" (13): one can take issue with the views of scholars like David Riggs, but labelling of this kind is not the way to do it.

MICHAEL KeEFER, University of Guelph

Martin, Jessica and Alec Ryrie (eds.). Private and Domestic Devotion in Early Modern Britain.

St. Andrews Studies in Reformation History. Farnham, UK and Burlington, VT: Ashgate, 2012. Pp. xi, $285+11$ ill. ISBN 978-1-14094-3131-2 (hardcover) $\$ 134.95$.

For the last 30 years, reappraisals of the Reformation by historians and literary scholars have produced some of the richest and most fascinating work in the field of early modern studies. For the most part, however, this research has focused on structural issues, notably theology, ecclesiology, and (perhaps especially) doctrine. This has done much to illuminate our understanding of essential sites of political and cultural contestation, and of the relationship between religion and state power; yet this preoccupation with structure has left several significant questions largely unaddressed. What, for instance, were the effects of the Reformation on the lives of individual believers? What can be said to constitute the experience of a Reformed faith among members of the laity? Private and Domestic Devotion in Early Modern Britain, a collection of essays edited by Jessica Martin and Alec Ryrie, establishes important groundwork for this conversation by calling attention to the subject of religious practice within 